\title{
Changes in the morphology and functions of vacuoles during the death of ray parenchyma cells in Cryptomeria japonica
}

\author{
Izumi Arakawa ${ }^{1} \cdot$ Ryo Funada $^{2} \cdot$ Satoshi Nakaba ${ }^{2}$
}

Received: 15 July 2017 / Accepted: 19 December 2017 / Published online: 17 January 2018

(C) The Japan Wood Research Society 2018

\begin{abstract}
Changes in the morphology and functions of vacuoles provide useful information about the mechanism of cell death. In the present study, we monitored the morphology and contents of vacuoles during the death of ray parenchyma cells in the conifer Cryptomeria japonica. In differentiating xylem, ray parenchyma cells had large central vacuoles. In sapwood, vacuoles in ray parenchyma cells contained proteins, an indication that one of the main functions of these vacuoles might be protein storage. A dramatic decrease in the protein content of some vacuoles was detected in the intermediate wood before the initiation of vacuole rupture. Although vacuole rupture was detected from the intermediate wood to the outermost heartwood, some vacuoles were obviously enlarged in the inner intermediate wood. Condensed nuclei were first observed after the rupture of these large vacuoles in ray parenchyma cells. It seems plausible that the autolysis of the contents of ray parenchyma cells might be caused by the rupture of the enlarged vacuoles in the inner intermediate wood.
\end{abstract}

Keywords Cell death $\cdot$ Heartwood formation $\cdot$ Ray parenchyma cell $\cdot$ Vacuole

\section{Introduction}

Wood consists of several kinds of secondary xylem cell that have a variety of functions. Cell death plays a critical role in the determination of the function of secondary xylem cells. Long-lived xylem ray parenchyma cells (ray parenchyma cells) retain their organelles for several years or decades, and they play important roles in the storage and radial transport of materials [1,2]. In addition, ray parenchyma cells are involved in the heartwood formation and they synthesize heartwood substances, such as polyphenols, that contribute to resistance to decay and the color and odor of wood, prior to their death [3-6]. In previous studies, we investigated the death of ray parenchyma cells as a model of

A part of this work was presented at the 66th Annual Meeting of Japan Wood Research Society, Nagoya, Japan, in March 2016.

Satoshi Nakaba

nakaba@cc.tuat.ac.jp

1 United Graduate School of Agricultural Science, Tokyo University of Agriculture and Technology, Fuchu, Tokyo 183-8509, Japan

2 Faculty of Agriculture, Tokyo University of Agriculture and Technology, Fuchu, Tokyo 183-8509, Japan the death of long-lived xylem cells in situ. The death of ray parenchyma cells does not occur successively even within the same radial cell lines of a ray, suggesting that the death of ray parenchyma cells might not be controlled in a timedependent manner [7-9]. Thus, the mechanism of the death of ray parenchyma cells might differ from that of the timedependent programmed cell death of short-lived tracheary elements $[10,11]$.

Morphological changes in and the functions of vacuoles have been used for the classification of programmed cell death in plants $[12,13]$, and it is necessary to clarify these features of vacuoles if we are to understand the mechanism of the death in ray parenchyma cells. In the case of xylem cells, morphological changes in and the functions of vacuoles have been well-characterized during the programmed cell death of short-lived xylem elements, in particular, the tracheary elements of cultured cells in the Zinnia system [11]. After completion of the formation of secondary walls, rupture of the large central vacuole caused autolysis of the nucleus and other organelles [14-16]. In contrast, the fragmentation of nuclear DNA was detected before vacuole rupture during cell death in wood fibers in Populus [17]. These observations indicate that patterns of organelle degradation differ between tracheary elements and wood fibers. However, much less information is available about morphological 
changes in and functions of vacuoles during the death of ray parenchyma cells. Enlargement of vacuoles $[18,19]$ and decrease in the number of organelles $[18,20]$ have been observed in the inner intermediate wood (white zone) of Cryptomeria japonica, but the functions of vacuoles during the death of ray parenchyma cells remain to be clarified.

In the present study, we monitored the timing of vacuole rupture, morphological changes, and the disappearance of nuclei during the death of ray parenchyma cells in $C$. japonica in an attempt to identify a relationship between the vacuole rupture and the autolysis of nuclei. In addition, we monitored changes in the morphological features and contents of vacuoles in the radial direction to determine where the death-related changes in vacuoles could first be detected. Finally, we assessed the functions of vacuoles during the death of long-lived ray parenchyma cells.

\section{Materials and methods}

\section{Plant materials}

Four $C$. japonica trees of approximately 38 years of age, growing at the Field Museum Tama Hills of the Tokyo University of Agriculture and Technology in Hachioji-Tokyo $\left(35^{\circ} 63^{\prime} \mathrm{N}, 139^{\circ} 37^{\prime} \mathrm{E}\right)$, were used in this study. Small blocks containing phloem, cambium and xylem, and incremental cores containing sapwood and heartwood were taken from stems at breast height. Samples were taken in May 2015, when secondary xylem was actively differentiating.

\section{Preparation of specimens}

Samples were fixed overnight at room temperature in a $4 \%$ solution of glutaraldehyde in $0.1 \mathrm{M}$ phosphate buffer $(\mathrm{pH}$ 7.2). Radial sections of approximately $40-\mu \mathrm{m}$ thickness were cut on the freezing stage of a sliding microtome (TU-213N; Yamatokohki, Saitama, Japan) and washed with the same buffer.

For the preparation of 1- $\mu \mathrm{m}$-thick sections, we selected four regions of xylem: the current and previous years' xylem (Fig. 1a), the middle part of the sapwood (Fig. 1b), the intermediate wood (Fig. 1c) and the outer part of the heartwood (Fig. 1d). Samples were trimmed into small blocks (longitudinal $\times$ tangential $\times$ radial direction, $2 \times 1 \times 3 \mathrm{~mm}^{3}$ ) and fixed for $2 \mathrm{~h}$ at room temperature in a $4 \%$ solution of glutaraldehyde in $0.1 \mathrm{M}$ phosphate buffer. After washing with the same buffer, the small blocks were immersed in $2 \%$ osmium tetroxide in the same buffer for $2 \mathrm{~h}$ at room temperature. Then, the blocks were washed with the same buffer, dehydrated through a graded ethanol series and embedded in epoxy resin (EPON812; TAAB, Berkshire, UK). Radial

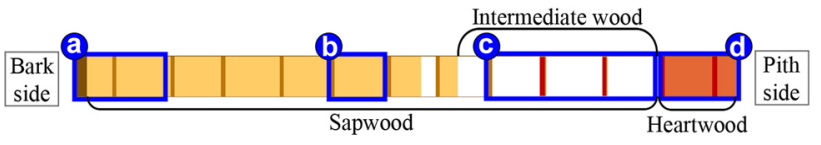

Fig. 1 A diagram showing the positions of samples used for the preparation of $1-\mu$ m-thick sections. Samples were collected from a the current and previous years' xylem, b the middle part of sapwood, c the intermediate wood and $\mathbf{d}$ the outer part of the heartwood. The definitions of intermediate wood and heartwood are described in "Terminology" in "Materials and methods"

sections of 1- $\mu \mathrm{m}$ thickness were cut with a glass knife on an ultramicrotome (Ultracut N; Reichert, Vienna, Austria).

\section{Morphology of nuclei and rates of survival of ray parenchyma cells}

It was previously shown that the death of ray parenchyma cells was associated with morphological changes and disappearance of nuclei $[8,9,21]$. To investigate the progress of the death of ray parenchyma cells, we observed morphology and disappearance of nuclei. Radial sections of 40- $\mu \mathrm{m}$ thickness were stained with a $1 \%$ aqueous solution of acetocarmine for observations of nuclei [21]. Sections were examined under a light microscope (Axio Scope. A1; Carl Zeiss, Oberkochen, Germany).

Rates of survival of ray parenchyma cells were calculated for each annual ring. Each rate was determined as the percentage of ray parenchyma cells that contained a nucleus among at least 100 ray parenchyma cells that were located in the middle part of the earlywood $[8,9]$.

\section{Visualization of starch grains, proteins and lipid droplets in ray parenchyma cells}

For observations of cellular contents, starch grains and proteins, radial sections of $1-\mu \mathrm{m}$ thickness were stained with a $1 \%$ aqueous solution of toluidine blue in $1 \%$ sodium borate [22], a $1 \%$ aqueous solution of iodine-potassium iodide $\left(\mathrm{I}_{2}-\mathrm{KI}\right)[23,24]$, and a $0.2 \%$ solution of amido black 10B (amido black) in 7\% acetic acid [9], respectively. For observations of lipid droplets, radial sections of $1-\mu \mathrm{m}$ thickness were examined without additional staining because lipid droplets had already been stained by osmium tetroxide. All the sections were examined under a light microscope (Axio Scope. A1 or Axioskop; Carl Zeiss, Oberkochen, Germany).

\section{Terminology}

Heartwood is defined as the inner layers of wood which, in the growing tree, have ceased to contain living cells [25]. In $C$. japonica, the color of xylem is also an indicator of heartwood. To show the relative radial positions in stems, 
we refer to xylem that is colored with heartwood substances as heartwood in this report.

In the present study, we use the term 'intermediate wood' for the white-colored xylem in the inner region of sapwood in the green condition. Our intermediate wood corresponds to the "white zone" of Nobuchi et al. [18] and Nobuchi and Harada [26].

\section{Results}

\section{Morphology of nuclei in ray parenchyma cells}

We observed nuclei, stained with acetocarmine, in ray parenchyma cells from the current year's xylem to the twelfth annual ring from the cambium. Fusiform and elliptical nuclei were detected in the current year's xylem (Fig. 2a, d). Their shapes changed to spherical from the current year's xylem toward the heartwood (Fig. 2b, e). Moreover, condensed and deformed nuclei were observed between the middle part and the inner part of the twelfth annual ring from the cambium (Fig. 2c, f).

\section{Rates of survival of ray parenchyma cells and color of xylem}

From the eighth to the eleventh annual rings from the cambium, we observed white-colored xylem, namely intermediate wood (shaded region in Fig. 3). In the inner part of the twelfth annual ring from the cambium, the color of the xylem changed to brown (the inner region of the intermediate wood in Fig. 3).

Death of ray parenchyma cells was detected first in the earlywood of the seventh annual ring from the cambium (an arrow in Fig. 3). After the start of cell death, rates of survival of ray parenchyma cells were high in the eighth and ninth annual rings from the cambium that is to say in the outer part of the intermediate wood. In the tenth and eleventh annual rings from the cambium, namely from the middle part to the inner part of the intermediate wood, many ray parenchyma
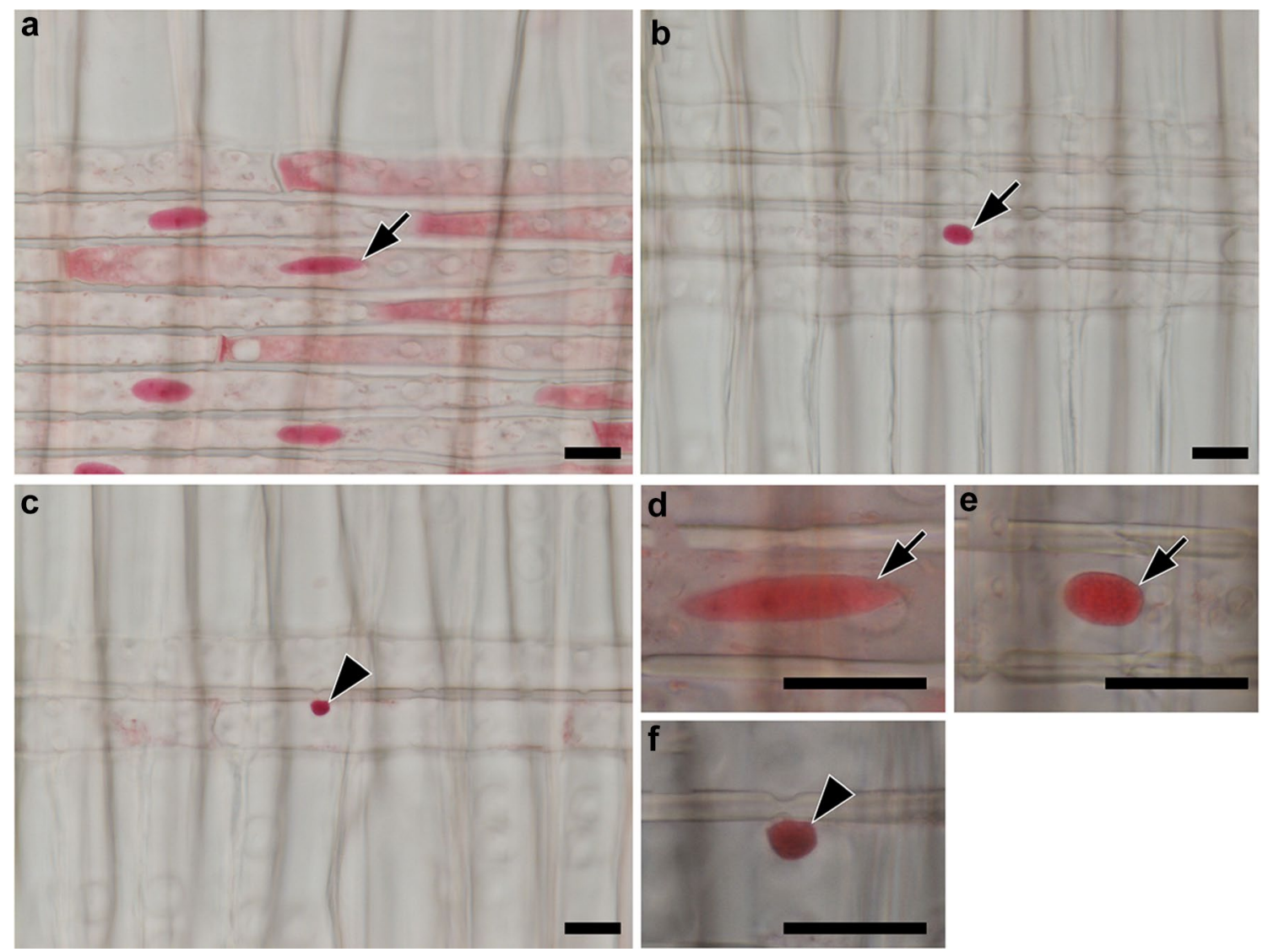

Fig. 2 Light micrographs of radial sections, stained with acetocarmine, showing nuclei in ray parenchyma cells $\mathbf{a}$ in the current year's xylem, $\mathbf{b}$ in the middle part of the twelfth annual ring from the cambium and $\mathbf{c}$ in the inner part of the twelfth annual ring from the cambium. Higher-magnification images of $\mathbf{d}$ a fusiform nucleus, $\mathbf{e}$ an elliptical nucleus and $\mathbf{f}$ a condensed nucleus are also shown. $\mathbf{d}-\mathbf{f}$ Higher-magnification images of $\mathbf{a}-\mathbf{c}$, respectively. Arrows indicate fusiform or elliptical nuclei. Arrowheads indicate condensed nuclei. Bars $20 \mu \mathrm{m}$ 


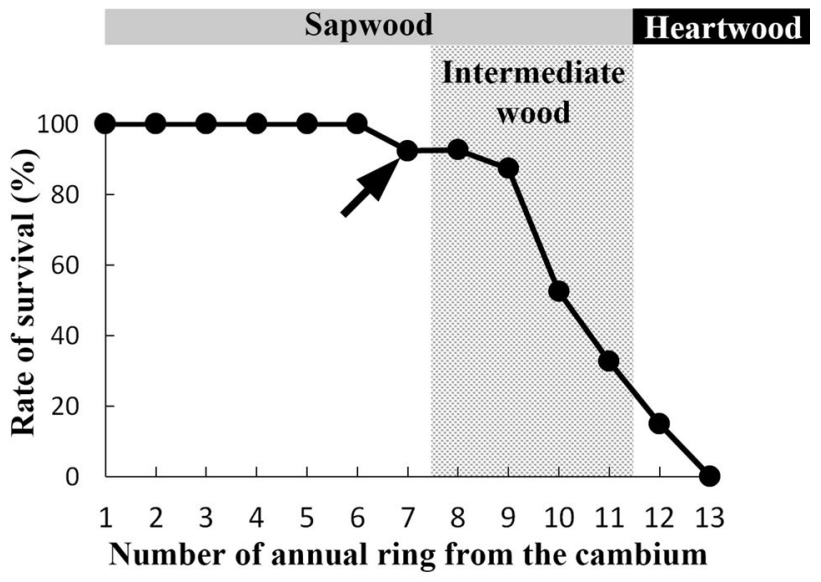

Fig. 3 The rates of survival of ray parenchyma cells, as determined from the current year's xylem to the annual ring in which all ray parenchyma cells had lost their organelles. An arrow indicates the first observed cell death. The shaded region indicates the intermediate wood. From the twelfth annual ring from the cambium to the pith, the color of xylem was typical of the heartwood of Cryptomeria japonica. The definitions of intermediate wood and heartwood are described in "Terminology" in "Materials and methods"

cells had died. Finally, no nuclei were detected in the innermost part of the twelfth annual ring from the cambium, namely, the outermost part of the heartwood.

\section{Contents of ray parenchyma cells in the previous year's xylem}

Radial serial sections of $1-\mu \mathrm{m}$ thickness were used for identification of the contents of ray parenchyma cells (Fig. 4). In the section without additional staining in Fig. 4a, lipid droplets were detected as osmiophilic substances (a yellow arrowhead). A nucleus was observed in the same section (a white arrow in Fig. 4a). Sections stained with toluidine blue yielded higher contrast than those without staining (Fig. 4b). Spherical or elliptical vacuoles that were smaller than nuclei were evident (black and white arrowheads in Fig. 4b), and some of them contained aggregates (a black arrowhead in Fig. 4b). Granular materials, stained by $\mathrm{I}_{2}-\mathrm{KI}$, were identified as starch grains (a black arrow in Fig. 4c). Furthermore, vacuoles containing aggregates were stained by amido black (a black arrowhead in Fig. 4d). These observations indicated that the aggregates in the vacuoles that had been stained by toluidine blue were proteins.

\section{Morphology and functions of vacuoles in ray parenchyma cells}

We investigated changes in the morphology and functions of vacuoles in the radial direction from the cambium towards heartwood after staining with toluidine blue (Fig. 5). We selected the following region as representative for detection of changes in vacuole function: the current year's xylem (differentiating xylem); the sixth annual ring from the cambium (middle part of the sapwood); and the region from the tenth to the twelfth annual rings from the cambium (from the intermediate wood to the outermost part of the heartwood) (Fig. 1).

In the inner earlywood of the current year's xylem (differentiating xylem), ray parenchyma cells had fusiform nuclei (a white arrow in Fig. 5a) and large central vacuoles (a black arrowhead in Fig. 5a). In the middle part of the earlywood in the sixth annual ring from the cambium (the middle part of the sapwood), elliptical nuclei (a white arrow in Fig. 5b) and many small vacuoles (black arrowheads in Fig. 5b) were found in the ray parenchyma cells. All of the small vacuoles contained proteins. In the middle part of the earlywood in the ninth annual ring from the cambium (the outer part of the intermediate wood), ray parenchyma cells had elliptical nuclei and vacuoles that contained proteins (data not shown).

In the middle part of earlywood in the tenth annual ring from the cambium (middle part of the intermediate wood), elliptical nuclei were observed in the ray parenchyma cells (a white arrow in Fig. 5c). Some vacuoles were obviously deformed and contained almost no protein (a white arrowhead in Fig. 5c). These deformed vacuoles had an irregular profile. By contrast, vacuoles that contained proteins were not deformed and had a smooth profile (a black arrowhead on the left side in Fig. 5c). In the middle part of the earlywood of the eleventh annual ring from the cambium (inner part of the intermediate wood), ray parenchyma cells had elliptical nuclei (a white arrow in Fig. 5d). The number of deformed vacuoles in each of the ray parenchyma cells tended to be greater than in the tenth annual ring from the cambium (white arrowheads in Fig. 5e). In addition, there were more ray parenchyma cells with deformed vacuoles than in the tenth annual ring from the cambium. Moreover, some large vacuoles had been observed but they had contained almost no protein (a black arrow in Fig. 5d). In some ray parenchyma cells, we observed both deformed vacuoles and large vacuoles (a black arrow and white arrowheads in Fig. 5d, e).

In the outer part of the earlywood in the twelfth annual ring from the cambium (outer region of the outermost part of the heartwood), ray parenchyma cells had elliptical nuclei (data not shown). In the same outer part of this earlywood, all the vacuoles were almost devoid of protein and many of them were obviously deformed (data not shown). In the middle part of the earlywood in the same annual ring (middle region of the outermost part of the heartwood), ray parenchyma cells had condensed nuclei (a white arrow in Fig. 5f). All vacuoles were deformed and contained almost no protein (white arrowheads in Fig. 5f). In the innermost part of the earlywood in the 

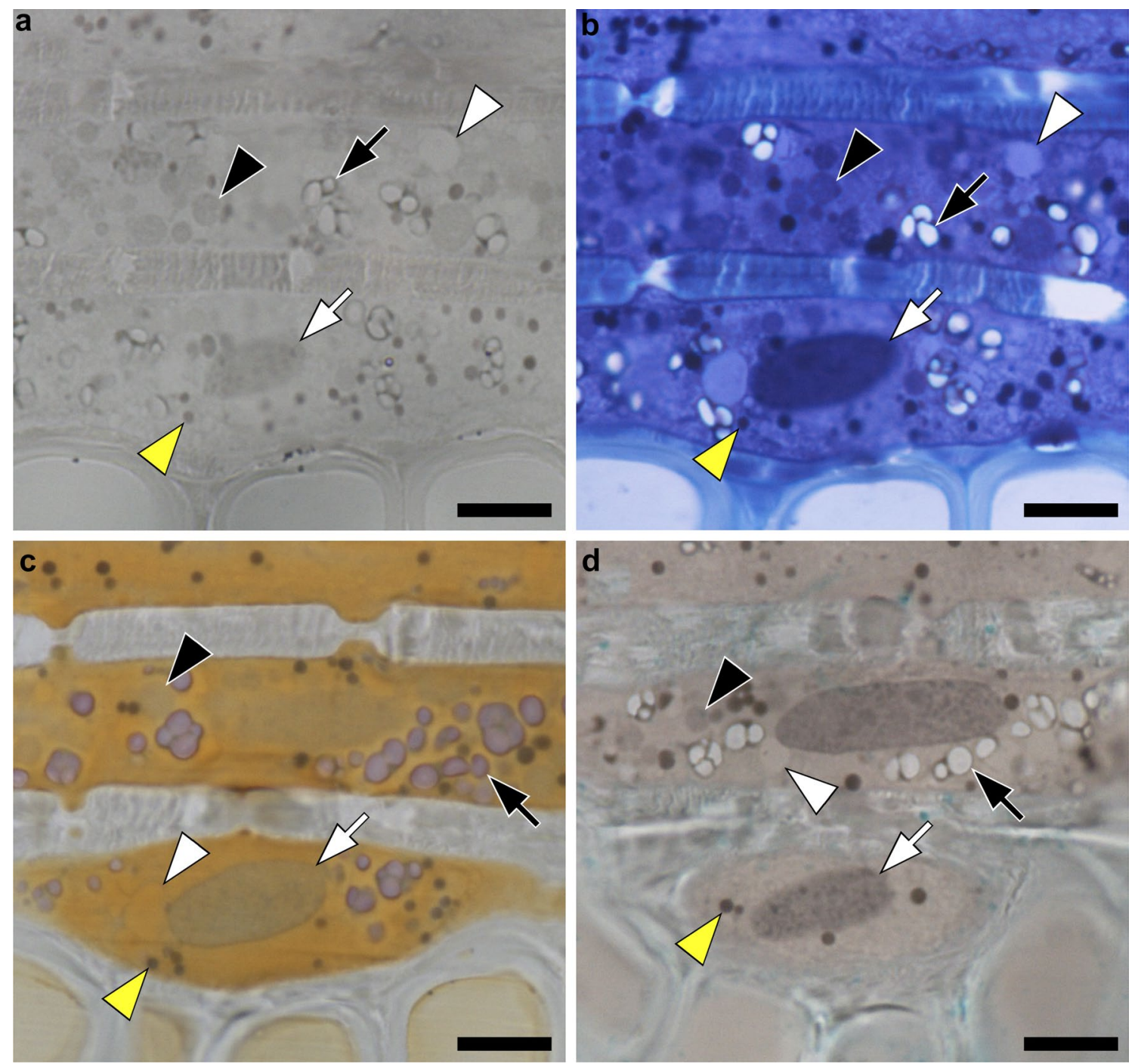

Fig. 4 Light micrographs of serial radial sections a without staining and $\mathbf{b}$ after staining with toluidine blue, $\mathbf{c}$ with iodine-potassium iodide and $\mathbf{d}$ with amido black in the previous year's xylem, showing the contents of ray parenchyma cells. White arrows indicate nuclei. Black arrows indicate starch grains. Yellow arrowheads indicate lipid droplets stained by osmium tetroxide. Black arrowheads indicate protein storage vacuoles (PSVs) stained by osmium tetroxide, toluidine blue and amido black. White arrowheads indicate non-PSVs that were unstained by these stains. Bars $10 \mu \mathrm{m}$

\section{Discussion}

Turgor pressure, which is caused by the uptake of water into vacuoles and increase in the volume of vacuoles, is important for the expansion and elongation of cells [27, 28]. In the current year's xylem, we observed large central vacuoles in the differentiating ray parenchyma cells (Figs. 5a, 6a). These large central vacuoles might be involved in the elongation of ray parenchyma cells.

In ray parenchyma cells from the previous year's xylem to the eleventh annual ring from the cambium, some fth annual ring from the cambium in $C$. japonica May, when secondary xylem was actively differentiating. 

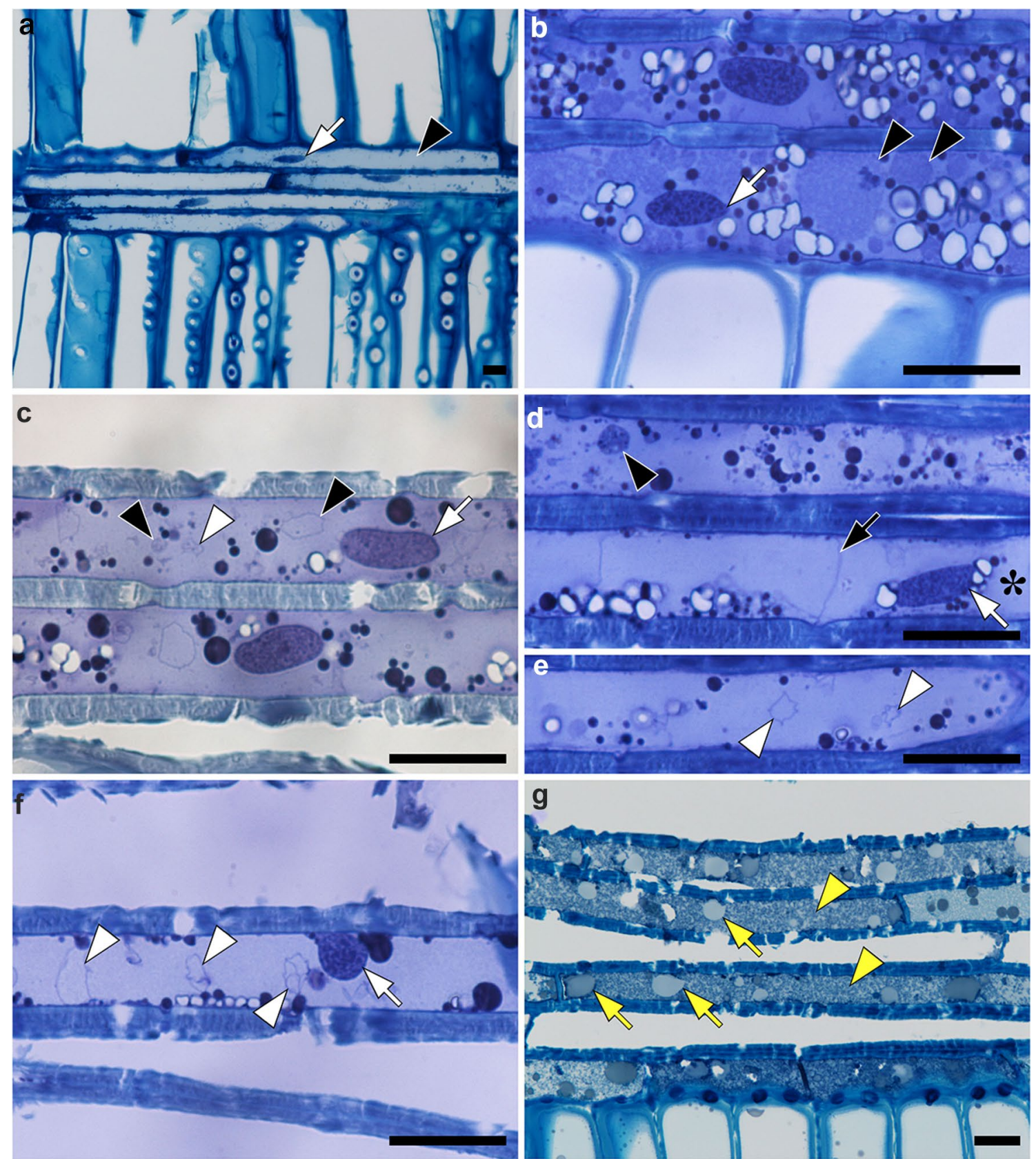

Fig. 5 Light micrographs of radial sections, stained with toluidine blue, showing vacuoles in ray parenchyma cells $\mathbf{a}$ in the current year's xylem (the differentiating xylem), $\mathbf{b}$ in the middle part of the sixth annual ring from the cambium (the middle part of sapwood), $\mathbf{c}$ in the middle part of the tenth annual ring from the cambium (the middle part of the intermediate wood), $\mathbf{d}, \mathbf{e}$ in the middle part of the eleventh annual ring from the cambium (the inner part of the intermediate wood), $\mathbf{f}$ in the middle part of the twelfth annual ring from the cambium (the middle region of the outermost part of the heartwood) and

vacuoles contained proteins (Figs. 4, 5b-d, 6b-d). In general, cells of the vegetative and generative organs of plants contain protein storage vacuoles (PSVs) [29, 30]. Thus, the vacuoles that were stained by toluidine blue and amido $\mathbf{g}$ in the inner part of the twelfth annual ring from the cambium (the inner region of the outermost part of the heartwood). Light micrograph (e) shows the inner part of the lower ray parenchyma cell in $\mathbf{d}$ (as indicated by an asterisk in d). White arrows indicate nuclei. Black arrowheads indicate protein storage vacuoles (PSVs) and non-PSVs. White arrowheads indicate deformed vacuoles. A black arrow indicates a large vacuole in the inner intermediate wood. Yellow arrowheads indicate osmiophilic aggregates and yellow arrows indicate lipid-like oily droplets in the heartwood. Bars $40 \mu \mathrm{m}$

black in ray parenchyma cells are likely to be PSVs. Hereafter, we use the abbreviation 'PSV' for a vacuole that was stained by toluidine blue and 'non-PSV' for a vacuole that was not stained by toluidine blue. 
【Differentiating xylem】

Current year's xylem

【Middle part of sapwood】

Sixth annual ring from the cambium

a
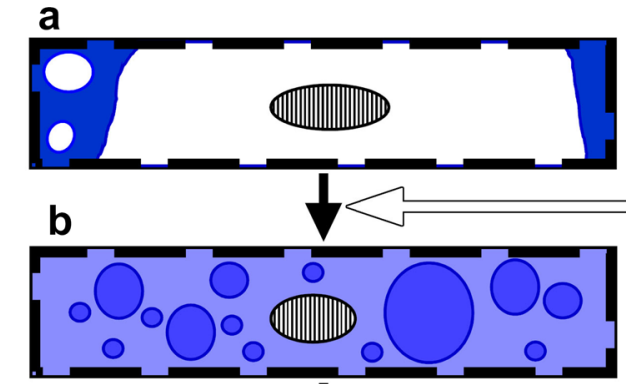

【Middle part of intermediate wood】

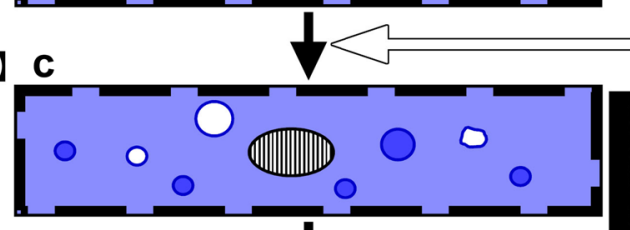

Initiation of decrease in proteins in some PSVs

\section{Tenth annual ring \\ from the cambium

【Inner part of intermediate wood】
Eleventh annual ring
from the cambium

【Outermost part of heartwood】
Twelfth annual ring
from the cambium
$<$ Middle region>
$<$ Mid le region>

$<$ Inner region $>$

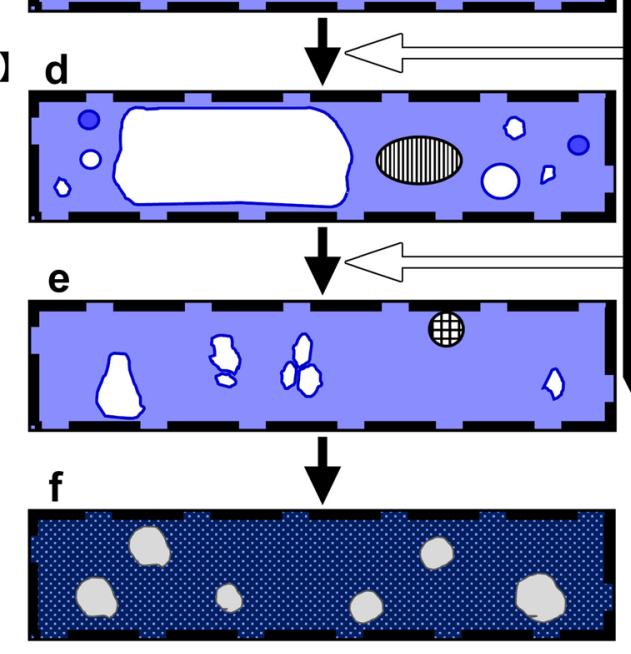

Protein accumulation in the vacuoles

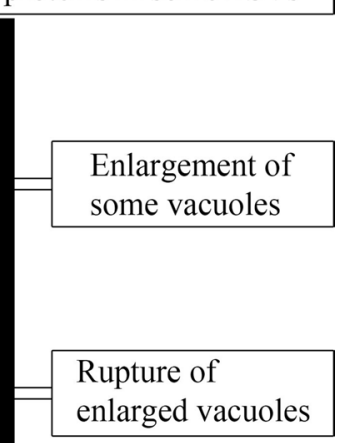

IIIID: Fusiform / elliptical nucleus $\bigcirc$ : Non-protein storage vacuole (non-PSV)

: Condensed / deformed nucleus $\bigcirc$ : Protein storage vacuole (PSV) $\bigcirc:$ Deformed vacuole

\section{: Lipid-like oily droplet : Osmiophilic aggregates}

Fig. 6 A diagram showing the timing of morphological changes in vacuoles and nuclei and changes in the contents of vacuoles in ray parenchyma cells from the elongation to the death of ray parenchyma cells in Cryptomeria japonica in May, when secondary xylem was actively differentiating. a In the current year's xylem (the differentiating xylem), ray parenchyma cells contained large central vacuoles and fusiform or elliptical nuclei. b In the sixth annual ring from the cambium (the middle part of the sapwood), ray parenchyma cells contained small protein storage vacuoles (PSVs) and elliptical nuclei. c In the tenth annual ring from the cambium (the middle part of intermediate wood), individual ray parenchyma cells contained PSVs, non-PSVs and deformed vacuoles but still had elliptical nuclei. d

In the previous year's xylem, ray parenchyma cells contained both PSVs and non-PSVs (Fig. 4). By contrast, in the sixth and ninth annual rings from the cambium, namely, in the middle part of the sapwood and the outer part of the intermediate wood, all the vacuoles in ray parenchyma cells were PSVs (Figs. 5b, 6b). These observations suggest that the main function of vacuoles in ray parenchyma cells might be storage of proteins from the
In the eleventh annual ring from the cambium (the inner part of the intermediate wood), the numbers of deformed vacuoles were greater than those in the outer part of the intermediate wood. In addition, they contained large vacuoles and elliptical nuclei. e In the middle part of the earlywood of the twelfth annual ring from the cambium (the middle region of the outermost part of the heartwood), ray parenchyma cells contained deformed vacuoles and condensed nuclei exclusively. f Finally, in the inner part of the earlywood of the twelfth annual ring from the cambium (the inner region of the outermost part of the heartwood), ray parenchyma cells contained lipid-like oily droplets and osmiophilic aggregates but no organelles

outer part of the sapwood to the outer part of the intermediate wood. It was reported that PSVs contain hydrolytic enzymes and function in autophagy, even when proteins are accumulated [29, 31]. Therefore, PSVs in ray parenchyma cells from the outer part of the sapwood to the outer part of the intermediate wood might also function in autophagy for maintenance of cellular homeostasis. 
From the middle part to the inner part of the intermediate wood, we observed deformed vacuoles in ray parenchyma cells (Figs. 5c-f, 6c-e). The profiles of these deformed vacuoles were irregular, suggesting that deformed vacuoles might have been ruptured. Some ray parenchyma cells contained ruptured vacuoles, as well as PSVs and/or non-PSVs (Figs. 5c-e, 6c, d). Both the number of ruptured vacuoles in each cell and the number of ray parenchyma cells that contained ruptured vacuoles increased from the middle part toward the inner part of the intermediate wood (Figs. $5 \mathrm{c}-\mathrm{f}$, $6 \mathrm{c}-\mathrm{e})$. Furthermore, there were no morphological changes in nuclei in ray parenchyma cells from the middle part to the inner part of the intermediate wood (Figs. 2b, e, 5c-e, 6c-d). During the programmed cell death of tracheary elements in the Zinnia system in vitro, the vacuole rupture is followed by the rapid degradation of nuclei and other organelles [14-16]. By contrast, ray parenchyma cells might retain their organelles for some time after the initiation of vacuole rupture (Figs. 5c-f, 6c-e).

Nobuchi and Harada [19] reported finding large vacuoles in the inner intermediate wood (white zone) of $C$. japonica by transmission electron microscopy. They suggested that these large vacuoles might be involved in autophagy [19]. In the present study, we identified the timing of rupture of these large vacuoles. In the inner part of the intermediate wood, some non-PSVs had clearly enlarged and others were ruptured (Figs. 5d, e, 6d). In the same region, all the ray parenchyma cells contained elliptical nuclei (Figs. 5d, 6d). In the middle region of the outermost part of the heartwood, all the vacuoles had been ruptured and ray parenchyma cells contained condensed nuclei (Figs. 5f, 6e). In the inner region of the outermost heartwood, only osmiophilic aggregates and some lipid-like oily droplets were observed (Figs. $5 \mathrm{~g}$, 6f). These observations suggest that dramatic changes associated with autolysis might start after the rupture of enlarged vacuoles. In tracheary elements, the autolysis of cellular contents follows rupture of a central vacuole [14-16]. Similarly, enlarged non-PSVs might play a critical role in the completion of autolysis of the contents of ray parenchyma cells in the inner part of the intermediate wood.

The present study revealed that vacuoles play important roles in protein storage in sapwood and the completion of autolysis in the inner part of the intermediate wood. In addition, we detected obvious changes in the contents of vacuoles in ray parenchyma cells in the intermediate wood. The number of PSVs tended to decrease and the number of non-PSVs tended to increase towards the inner part of the intermediate wood (Figs. 5c-f, 6c-e). It was reported that PSVs are converted into large central lytic vacuoles (LVs) by degradation of storage proteins and accumulated hydrolytic enzymes in the vacuoles of aleurone cells during endosperm maturation in cereal grains [29]. It is possible that these large central LVs are involved in the final quick degradation of the cytoplasmic contents due to the vacuole rupture and release of hydrolytic enzymes into the cytoplasm [13, 29]. Similar changes in vacuoles might occur in ray parenchyma cells from the outer part to the inner part of the intermediate wood. Therefore, the initial change in vacuoles might be a dramatic decrease in storage proteins in the intermediate wood during the death of ray parenchyma cells.

In this study, we investigated the timing of vacuole rupture, morphological changes, and the disappearance of nuclei during the death of ray parenchyma cells in $C$. japonica in May, when secondary xylem was actively differentiating. Our observations suggest the following three characteristics of changes in vacuoles; (1) the initial change in vacuoles might be a dramatic decrease in storage proteins in PSVs in the intermediate wood; (2) in ray parenchyma cells in the intermediate wood, not all vacuoles are ruptured at the same time even in the same cells; and (3) rupture of enlarged vacuoles might result in autolysis of cellular contents in ray parenchyma cells in the outermost part of the heartwood.

Acknowledgements The authors thank Dr. Kazuhide Matsuda (Faculty of Agriculture, Tokyo University of Agriculture and Technology) and the staff of the Field Museum Tama Hills of the Tokyo University of Agriculture and Technology for providing plant materials. This work was supported by JSPS KAKENHI Grant numbers JP15H04527, JP15K07508, JP16J04359, JP16K14954.

\section{Compliance with ethical standards}

Conflict of interest The authors declare that they have no conflict of interest.

\section{References}

1. Sauter JJ (2000) Photosynthate allocation to the vascular cambium: facts and problems. In: Savidge RA, Barnett JR, Napier $\mathrm{R}$ (eds) Cell and molecular biology of wood formation. BIOS Scientific Publishers, Oxford, pp 71-83

2. Spicer R (2014) Symplasmic networks in secondary vascular tissues: parenchyma distribution and activity supporting longdistance transport. J Exp Bot 65:1829-1848

3. Hillis WE (1987) Heartwood and tree exudates. Springer, New York, pp 1-268

4. Magel EA (2000) Biochemistry and physiology of heartwood formation. In: Savidge RA, Barnett JR, Napier R (eds) Cell and molecular biology of wood formation. BIOS Scientific Publishers, Oxford, pp 363-376

5. Taylor AM, Gartner BL, Morrell JJ (2002) Heartwood formation and natural durability - a review. Wood Fiber Sci 34:587-611

6. Spicer R (2005) Senescence in secondary xylem: heartwood formation as an active developmental program. In: Holbrook NM, Zwieniecki MA (eds) Vascular transport in plants. Elsevier Academic Press, Amsterdam, pp 457-475

7. Nakaba S, Sano Y, Kubo T, Funada R (2006) The positional distribution of cell death of ray parenchyma in a conifer, Abies sachalinensis. Plant Cell Rep 25:1143-1148

8. Nakaba S, Yoshimoto J, Kubo T, Funada R (2008) Differences in patterns of cell death between ray parenchyma cells and ray 
tracheids in the conifers Pinus densiflora and Pinus rigida. Trees Struct Funct 22:623-630

9. Nakaba S, Begum S, Yamagishi Y, Jin HO, Kubo T, Funada R (2012) Differences in the timing of cell death, differentiation and function among three different types of ray parenchyma cells in the hardwood Populus sieboldii $\times$ P. grandidentata. Trees Struct Funct 26:743-750

10. Escamez S, Tuominen H (2014) Programmes of cell death and autolysis in tracheary elements: when a suicidal cell arranges its own corpse removal. J Exp Bot 65:1313-1321

11. Fukuda H (2004) Signals that control plant vascular cell differentiation. Nat Rev Mol Cell Biol 5:379-391

12. van Doorn WG, Woltering EJ (2005) Many ways to exit? Cell death categories in plants. Trends Plant Sci 10:117-122

13. van Doorn WG, Beers EP, Dangl JL, Franklin-Tong VE, Gallois P, Hara-Nishimura I, Jones AM, Kawai-Yamada M, Lam E, Mundy J, Mur LAJ, Petersen M, Smertenko A, Taliansky M, Van Breusegem F, Woltering E, Ahivotovsky B, Bozhknov PV (2011) Morphological classification of plant cell deaths. Cell Death Differ 18:1241-1246

14. Groover A, DeWitt N, Heidel A, Jones A (1997) Programmed cell death of plant tracheary elements differentiating in vitro. Protoplasma 196:197-211

15. Kuriyama H (1999) Loss of tonoplast integrity programmed in tracheary element differentiation. Plant Physiol 121:763-774

16. Obara K, Kuriyama H, Fukuda H (2001) Direct evidence of active and rapid nuclear degradation triggered by vacuole rupture during programmed cell death in Zinnia. Plant Physiol 125:615-626

17. Courtois-Moreau CL, Pesquet E, Sjödin A, Muñiz L, Bollhöner B, Kaneda M, Samuels L, Jansson S, Tuominen H (2009) A unique program for cell death in xylem fibers of Populus stem. Plant $\mathbf{J}$ 58:260-274

18. Nobuchi T, Kuroda K, Iwata R, Harada H (1982) Cytological study of the seasonal features of heartwood formation of sugi (Cryptomeria japonica D. Don). Mokuzai Gakkaishi 28:669-676

19. Nobuchi T, Harada H (1985) Ultrastructural changes in parenchyma cells of sugi (Cryptomeria japonica D. Don) associated with heartwood formation. Mokuzai Gakkaishi 31:965-973
20. Nobuchi T, Harada H (1968) Electron microscopy of the cytological structure of the ray parenchyma cells associated with heartwood formation of sugi (Cryptomeria japonica D. Don). Mokuzai Gakkaishi 14:197-202

21. Nakaba S, Sano Y, Funada R (2013) Disappearance of microtubules, nuclei and starch during cell death of ray parenchyma in Abies sachalinensis. IAWA J 34:135-146

22. Kudo K, Yasue K, Hosoo Y, Funada R (2015) Relationship between formation of earlywood vessels and leaf phenology in two ring-porous hardwoods, Quercus serrata and Robinia pseudoacacia, in early spring. J Wood Sci 61:455-464

23. Begum S, Nakaba S, Oribe Y, Kubo T, Funada R (2007) Induction of cambial reactivation by localized heating in a deciduous hardwood hybrid poplar (Populus sieboldii $\times$. grandidentata). Ann Bot 100:439-447

24. Nakaba S, Morimoto H, Arakawa I, Yamagishi Y, Nakada R, Funada R (2017) Responses of ray parenchyma cells to wounding differ between earlywood and latewood in the sapwood of Cryptomeria japonica. Trees Struct Funct 31:27-39

25. IAWA (Committee on Nomenclature, International Association of Wood Anatomists) (1964) Multilingual glossary of terms used in wood anatomy. Verlagsanstalt Buchdruckerei Konkordia, Winterthur

26. Nobuchi T, Harada H (1983) Physiological features of the "white zone" of sugi (Cryptomeria japonica D. Don)—cytological structure and moisture content. Mokuzai Gakkaishi 29:824-832

27. Martin C, Bhatt K, Baumann K (2001) Shaping in plant cells. Curr Opin Plant Biol 4:540-549

28. Dolan L, Davies J (2004) Cell expansion in roots. Curr Opin Plant Biol 7:33-39

29. Müntz K (2007) Protein dynamics and proteolysis in plant vacuoles. J Exp Bot 58:2391-2407

30. Smith AM, Coupland G, Dolan L, Harberd N, Jones J, Martin C, Sablowski R, Amey A (2010) Cells. In: Plant biology. Garland Science, New York, pp 91-166

31. Hoh B, Hinz G, Jeong BK, Robinson DG (1995) Protein storage vacuoles form de novo during pea cotyledon development. J Cell Sci 108:299-310 